\title{
ICDD ACTIVITIES AT THE 1997 DENVER CONFERENCE
}

This August, the Technical Committee of the International Centre for Diffraction Data will meet at the Denver X-ray Conference (4-8 August 1997) in Steamboat Springs, Colorado. The Technical Committee is the way members (and nonmembers) can provide input for project and product evaluations and recommendations for new projects and products into the operations of ICDD. The Technical Committee is also a forum for new innovations in X-ray analysis where active scientists present new ideas and concepts to members.

Several of the Subcommittees, including the new subcommittee on XRF activities, will be meeting at various times during the Conference. All meeting times and places will be posted on the Conference information bulletin board. The Technical Committee will meet on Friday morning. Functionally, recommendations are generated in task groups and in the subcommittees and are then presented to the Technical Committee for forum and action. Recommendations which pass the Technical Committee are submitted to the Board of Directors which evaluate the technical and financial merit and the ability of the permanent staff of ICDD to carry out the proposed project. All the Technical Committee meetings are open to all DXC attendees. In fact, attendees are urged to participate to learn how ICDD operates.

The subcommittee meetings and the Technical Committee meeting will be scheduled at times of minimum conflict with other DXC activities. Some of the subcommittee meetings which are planned are:

Ceramics

Crystallographically Derived Patterns

Data Collection and Analysis

Metals and Alloys

Minerals

Organics and Forensics

Target Systems

$\mathrm{X}$-ray Fluorescence
Membership in ICDD is open to all interested individuals who want to contribute to the goals of the organization. The goals are to provide products useful to the X-ray analysis community and to lead in the education of the proper use of these products and data. The primary product of ICDD is the Powder Diffraction File and related software, but there are many other activities including preparing directed subset products, instructional materials and courses, sponsoring grants-in-aid and scholarships, participating in and organizing international meetings, and making recommendations to other organizations for products needed by the analysis community such as standards. Any individual interested in membership should contact a present member who will present the name to the Membership Committee for processing through the by-law defined procedure. Alternatively, an individual may also indicate interest in membership by contacting directly the ICDD General Maanger, Ron Jenkins (jenkins@icdd.com) or the Membership Committee Chairman, James Kaduk (kaduk@icdd.com).

Participants at the DXC are urged to participate in as many of the ICDD meetings as possible during the busy week. As attendees of the DXC, you have a special interest in ICDD because it is the organization that will be responsible for the operation of the DXC in the future. Learn what ICDD does and how it operates and how you might join and participate in the programs. 